\title{
REVIEW
}

\section{Hepcidin and Iron Metabolism in Experimental Liver Injury}

\author{
Steven A. Bloomer* and Kyle E. Brown ${ }^{\dagger \uparrow \S}$
}

From the Division of Science and Engineering, * Penn State Abington, Abington, Pennsylvania; the Iowa City Veterans Administration Medical Center, ${ }^{\dagger}$ Iowa City, Iowa; the Division of Gastroenterology-Hepatology, ${ }^{\ddagger}$ Department of Internal Medicine, and the Program in Free Radical and Radiation Biology, ${ }^{\S}$ Department of Radiation Oncology, University of Iowa Carver College of Medicine, Iowa City, Iowa

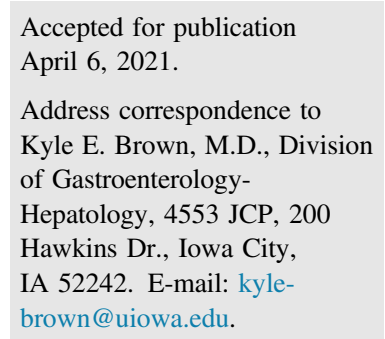

\begin{abstract}
The liver plays a pivotal role in the regulation of iron metabolism through its ability to sense and respond to iron stores by release of the hormone hepcidin. Under physiologic conditions, regulation of hepcidin expression in response to iron status maintains iron homeostasis. In response to tissue injury, hepcidin expression can be modulated by other factors, such as inflammation and oxidative stress. The resulting dysregulation of hepcidin is proposed to account for alterations in iron homeostasis that are sometimes observed in patients with liver disease. This review describes the effects of experimental forms of liver injury on iron metabolism and hepcidin expression. In general, models of acute liver injury demonstrate increases in hepcidin mRNA and hypoferremia, consistent with hepcidin's role as an acute-phase reactant. Conversely, diverse models of chronic liver injury are associated with decreased hepcidin mRNA but with variable effects on iron status. Elucidating the reasons for the disparate impact of different chronic injuries on iron metabolism is an important research priority, as is a deeper understanding of the interplay among various stimuli, both positive and negative, on hepcidin regulation. Future studies should provide a clearer picture of how dysregulation of hepcidin expression and altered iron homeostasis impact the progression of liver diseases and whether they are a cause or consequence of these pathologies. (Am J Pathol 2021, 191: 1165-1179; https://doi.org/10.1016/j.ajpath.2021.04.005)
\end{abstract}

The liver is the primary source of numerous proteins involved in the regulation of iron metabolism, including hepcidin, ferritin, and transferrin. In addition to their roles in iron metabolism, these proteins are acute-phase reactants whose expression can be altered in response to hepatic or systemic injury or inflammation. Several common human liver diseases, including alcoholic liver disease, nonalcoholic fatty liver disease (NAFLD), and chronic hepatitis $\mathrm{C}$, are often accompanied by increases in serum iron, transferrin saturation, and/or ferritin levels. Less commonly, hepatic iron content is increased in these conditions. These alterations in iron metabolism have been linked to adverse clinical outcomes. $^{1-4}$ Thus, there is substantial interest in understanding the mechanisms responsible for dysregulation of iron metabolism in liver disease. The aim of this article is to provide an overview of studies that have examined hepcidin expression and dysregulation of iron metabolism in various forms of experimental liver injury.

\section{Hepcidin and Regulation of Iron Metabolism}

The existence of a physiologic mechanism that maintains iron homeostasis by enhancing absorption of dietary iron when iron stores are low and diminishing absorption when iron stores are replete has been known for many decades. The identity of the primary regulator of these phenomena was revealed in 2001 with the discovery of hepcidin (gene name Hamp). ${ }^{5,6}$ A small peptide produced by the liver, hepcidin causes degradation of the iron export protein ferroportin, which is required for the transfer of iron from enterocytes and macrophages to the systemic circulation. Numerous investigators using a variety of methods of iron administration have demonstrated increases in Hamp mRNA in response to iron. ${ }^{5,8,9}$ These results support the prevailing paradigm whereby hepcidin expression is upregulated by increased iron stores. Conversely, low hepcidin 
enhances iron absorption from the gut, leading to restoration of iron stores. The observations that the liver is the primary source of hepcidin and that many forms of iron overload are characterized by hepcidin levels that are inappropriately low relative to iron stores form the basis for the hypothesis linking aberrant regulation of hepcidin expression to dysregulated iron metabolism in the context of liver disease.

Regulation of Hamp expression is surprisingly complex and remains incompletely understood. A comprehensive review of this topic is beyond the scope of this article, but basic knowledge of the mechanisms that regulate hepcidin gene expression is needed to understand the potential means by which liver injury can alter iron metabolism. At a fundamental level, members of the bone morphogenetic protein (BMP) family play key roles in integrating signals that regulate hepcidin expression in response to iron status. This process is achieved by the binding of specific BMPs to BMP type II receptors, which phosphorylate BMP type I receptors, activating the SMAD 1/5/8 pathway and leading to the formation of a heteromeric complex with Smad4 that translocates to the nucleus to stimulate hepcidin gene expression. ${ }^{10,11}$

BMPs appear to modulate hepcidin expression by two separate pathways. The first of these accounts for the ability of hepatocytes to increase Hamp mRNA in response to increases in serum iron. Serum iron circulates bound to transferrin (Tf), forming holo-Tf. HFE, the product of the gene whose mutations are responsible for the most common form of hereditary hemochromatosis $(\mathrm{HH})$, forms a complex with transferrin receptor 1 (TFR1) on the plasma membrane of hepatocytes. The interaction of holo-Tf with TFR1 has been suggested to cause dissociation of HFE from its complex with TFR1, allowing HFE to bind to transferrin receptor 2 (TFR2), followed by binding of the HFE-TFR2 complex to the BMP coreceptor, membrane-bound hemojuvelin. ${ }^{10,12}$ Subsequent steps in this signaling pathway that lead to modulation of hepcidin gene expression are proposed to involve BMP2. ${ }^{13}$ The second mechanism by which hepcidin expression is modulated by iron status is mediated by paracrine production of BMP6 by hepatic nonparenchymal cells. Although studies that used different rodent species and different methods provided conflicting data regarding the cell type or types responsible for expression of BMP6 in the liver, conditional knockout of Bmp6 in sinusoidal endothelial cells (SECs) was associated with reduced hepcidin expression and increased hepatic iron content, indicating a key role for SEC BMP6 in iron metabolism. ${ }^{14-17}$ BMP6 levels increase in response to increases in liver iron, a phenomenon that has been linked to enhanced nuclear factor erythroid-2-related factor 2 signaling in SECs resulting from oxidative stress. ${ }^{18,19}$

The requirement for these components for normal regulation of iron metabolism is illustrated by studies in which they have been genetically ablated in mice. As noted above, most cases of $\mathrm{HH}$ in humans are caused by mutations in the HFE gene, which causes hepatic iron overload because of inappropriately low hepcidin expression. Hfe knockout mice have lower Hamp mRNA than their wild-type counterparts despite threefold to eightfold greater hepatic iron content. ${ }^{20,21}$ These mice also fail to induce hepcidin in response to iron administration. ${ }^{22}$ Expression of a hepcidin transgene reverses the iron overload phenotype of $\mathrm{Hfe}^{-/-}$mice. ${ }^{23}$ Complete or conditional knockout of $T f r 2$ results in increases in hepatic iron, ranging from approximately twofold to $>20$-fold compared with wild-type controls. ${ }^{24,25} T f r 2$ mutant mice (TfR2 Y245X mutant) demonstrate lower baseline levels of hepcidin and a markedly attenuated induction of Hamp mRNA in response to iron overload. ${ }^{24} \mathrm{Hjv}^{-/}$mice develop heavy hepatic iron deposition (approximately 20 -fold increase), lack of hepcidin expression, and an inability to induce hepcidin in response to iron administration. ${ }^{26}$ Liver iron is increased approximately 10-fold in Bmp6 knockout mice, in which hepcidin expression is greatly attenuated $\left(<10 \%\right.$ of wild-type controls). ${ }^{27}$ Consistent with these observations, mutations in TFR2, HJV, and BMP6 are rare causes of $\mathrm{HH}$ in humans. ${ }^{28-30}$

\section{Regulation of Hepcidin Expression by Inflammation}

Classic experiments showing that lipopolysaccharide administration causes hypoferremia demonstrated that inflammation modulates iron metabolism. ${ }^{31}$ The mechanism of inflammation-driven hypoferremia is now understood to involve the effects of inflammatory cytokines (particularly IL-6) via STAT-3 on hepcidin gene expression. $^{32,33}$ An acute-phase protein, hepcidin is also regulated by other cytokines, including tumor necrosis factor (TNF)- $\alpha$ and IL-1 $\beta$, which can contribute to the hypoferremic response but seem to be less important than IL-6. ${ }^{34-36}$ Increases in hepcidin mRNA are driven by increased hepatic expression of inflammatory cytokines during the acute-phase response, but hepatic hepcidin expression is upregulated by circulating cytokines that arise from inflammation distant to the liver in some models. ${ }^{37}$ Endoplasmic reticulum stress that results from the acute inflammatory response also contributes to induction of hepcidin via the cAMP response element-binding protein $\mathrm{H}$, which activates the hepcidin promoter. ${ }^{38}$ In addition to blocking intestinal iron uptake, hepcidin-mediated degradation of ferroportin in macrophages impairs the constitutive export of iron from these cells, augmenting hepcidin's hypoferremic effect. Hypoferremia and reticuloendothelial cell iron retention ensue rapidly after injection of hepcidin or IL-6 in experimental animals. ${ }^{39-41}$ This retention is presumed to serve an adaptive function, lowering plasma iron to limit its availability to pathogens and thus limiting their proliferation. Although inflammation-induced hypoferremia may be 
protective in the context of bacterial infection, in chronic inflammatory states, sequestration of iron caused by persistent induction of hepcidin results in the anemia of chronic disease, also known as the anemia of inflammation.

Another important transcription factor that regulates the expression of hepcidin is CCAAT enhancer-binding protein $\alpha(\mathrm{C} / \mathrm{EBP} \alpha)$, which modulates responses to both inflammatory stimuli and to changes in hepatic iron. The Hamp promoter region contains binding sites for both STAT-3 and $\mathrm{C} / \mathrm{EBP} \alpha$, indicating convergence of these two pathways during inflammatory responses. ${ }^{42-44}$ Liver-specific knockout of $C / E B P \alpha$ results in marked attenuation of hepcidin expression and hepatic iron overload. ${ }^{43}$ Furthermore, chronic hepatic iron overload is associated with upregulation of $C / E B P \alpha$ and Hamp expression. ${ }^{44,45} \mathrm{C} / \mathrm{EBP} \alpha$-mediated regulation of hepcidin is itself modulated by the upstream regulator CCAAT enhancer-binding protein homologous protein (CHOP), which inhibits C/EBP $\alpha$ DNAbinding activity. In chronic iron overload that results from exogenous iron administration, CHOP protein levels were reduced and $\mathrm{C} / \mathrm{EBP} \alpha$ protein and hepcidin mRNA increased. ${ }^{45}$

\section{Other Modulators of Hepcidin Expression: Erythropoiesis}

Conversely, anemia and hypoxia upregulate iron absorption and reticuloendothelial efflux of iron via suppression of hepcidin. Under these conditions, the kidney releases erythropoietin (EPO), which stimulates increased incorporation of iron into red blood cell precursors in the bone marrow, lowering transferrin iron saturation and thus inhibiting the expression of hepcidin by the pathway described above. However, EPO exerts an additional hepcidin-lowering effect via the stimulation of the production of erythroferrone (ERFE) in bone marrow erythroblasts. $^{46}$ ERFE suppresses hepcidin expression in hepatocytes by interfering with SMAD signaling. ${ }^{11}$ Hamp mRNA and plasma hepcidin are rapidly downregulated in response to phlebotomy or EPO; both stimuli reduced hepcidin mRNA expression threefold within 12 hours, along with an approximate $90 \%$ reduction in plasma hepcidin at the same time point. These responses were attenuated in Fam132b (the ERFE gene) knockout mice and Faml32b haploinsufficient mice. ${ }^{46}$ Thus, short-term stimulation of erythropoietic activity depresses hepcidin expression, leading to enhanced intestinal iron absorption, thereby restoring homeostasis. EPO is also an acute-phase reactant, and enhanced hepatic Epo expression after acute inflammatory stimuli is dependent on induction of IL- $6 .{ }^{35}$ In addition to tissue-protective effects unrelated to its hematopoietic function, induction of $E P O$ has been proposed to serve as a compensatory response to limit the anemia of inflammation induced by hepcidin. ${ }^{47}$

\section{Hepcidin and Iron Metabolism in Models of Liver Injury}

\author{
Models of Acute Liver Injury
}

Various models have been used to examine the effect of acute liver injury on hepcidin (Table 1). ${ }^{48-53}$ In an early study, Goss et $\mathrm{al}^{48}$ examined the effects of liver ischemiareperfusion on hepcidin. These authors observed that either 45 minutes of hepatic ischemia without reperfusion (IO) or 45 minutes of ischemia followed by 60 minutes of reperfusion (I-R) resulted in significant increases in Hamp mRNA compared with animals undergoing sham operations. Serum hepcidin levels paralleled the changes in gene expression, and in both the IO and I-R groups, serum iron decreased, consistent with the expected effect of increased hepcidin. Serum IL-6 levels were unchanged in the IO and I-R groups versus controls undergoing sham operations. Thus, the mechanism responsible for induction of hepcidin in this study was not identified.

Several groups have assessed the effects of partial hepatectomy (PH) on hepcidin expression. ${ }^{49-51}$ Despite minor variations in experimental design, they consistently demonstrated a biphasic effect of PH on Hamp mRNA, with an increase in the first 24 hours, followed by suppression to levels below that of controls undergoing sham operations for as long as 1 week after PH. Transient increases in serum IL-6 after PH appeared to account for the early induction of hepcidin expression. Serum iron levels decreased rapidly after $\mathrm{PH}$, in some cases preceding the increase in Hamp expression. Furthermore, Sheikh et $\mathrm{al}^{49}$ observed hypoferremia after PH that persisted for at least 48 hours without significant change in serum prohepcidin levels.

The same study ${ }^{49}$ found that the effects of acute toxic liver injury on iron metabolism and hepcidin expression were similar to those seen after PH. Hepcidin transcript levels increased modestly but significantly within 3 hours after administration of a single dose of carbon tetrachloride $\left(\mathrm{CCl}_{4}\right)$, returning to control values by 24 hours. Hepatic IL6 , IL- $1 \beta$, TNF- $\alpha$, and IFN- $\gamma$ mRNA levels increased markedly after $\mathrm{CCl}_{4}$, whereas changes in the serum levels of these mediators were delayed and of lesser magnitude, suggesting that local cytokine production was the primary factor driving early increases in hepcidin expression. As in the PH model, serum iron levels decreased significantly 3 hours after $\mathrm{CCl}_{4}$ treatment and remained low up to 48 hours afterward, with no change in serum prohepcidin levels for the first 24 hours. The mechanism of hypoferremia in the absence of increased Hamp mRNA and/or serum prohepcidin in these models remains unexplained.

Christiansen et $\mathrm{al}^{52}$ evaluated iron metabolism and hepcidin expression in rats after a single $25-\mathrm{Gy}$ dose of radiation to the liver. Hamp mRNA increased significantly 24 hours after liver irradiation and was preceded by elevated levels of transcripts for several inflammatory mediators (IL$1 \beta, \mathrm{IL}-6$, and TNF- $\alpha$ ) in the livers, peaking at 6 hours after 
Table 1 Effects of Acute Liver Injury on Hepcidin and Iron Metabolism

\begin{tabular}{|c|c|c|c|c|c|c|}
\hline Model & $\begin{array}{l}\text { Experimental } \\
\text { animal }\end{array}$ & $\begin{array}{l}\text { Effect on liver } \\
\text { histologic findings }\end{array}$ & $\begin{array}{l}\text { Effect on hepatic } \\
\text { iron } \\
\text { content }\end{array}$ & Effect on hepcidin & Comments & Reference \\
\hline I-R & $\begin{array}{l}\text { Male Sprague- } \\
\text { Dawley rats }\end{array}$ & Not reported & Not reported & $\begin{array}{l}\text { Increase in } \\
\text { hepcidin mRNA }\end{array}$ & $\begin{array}{l}\text { Serum iron } \\
\text { decreased in } \\
\text { animals treated } \\
\text { with either } \\
\text { ischemia alone or } \\
\text { with I-R }\end{array}$ & 48 \\
\hline $\begin{array}{l}\mathrm{PH} \text { or } \mathrm{CCl}_{4}, 3 \\
\mathrm{~mL} / \mathrm{kg} \text { gavage } \\
\quad \times 1\end{array}$ & Male Wistar rats & Not reported & Not reported & $\begin{array}{l}\text { Hepcidin mRNA } \\
\text { significantly } \\
\text { increased } 4,8 \text {, } \\
\text { 16, and } 24 \text { hours } \\
\text { after } \mathrm{PH} \text {; } \\
\text { hepcidin mRNA } \\
\text { significantly } \\
\text { increased } 3,6 \text {, } \\
\text { and } 12 \mathrm{hours} \\
\text { after } \mathrm{CCl}_{4}\end{array}$ & $\begin{array}{l}\mathrm{PH} \text { and } \mathrm{CCl}_{4} \\
\text { decreased serum } \\
\text { iron for up to } 48 \\
\text { hrs; serum } \\
\text { pro-hepcidin not } \\
\text { altered after } \mathrm{PH} \text {, } \\
\text { but increased } \\
\text { approximately } \\
40 \% \text { after } \mathrm{CCl}_{4} \\
\text { only at } 48 \mathrm{hrs}\end{array}$ & 49 \\
\hline $\mathrm{PH}$ & $\begin{array}{l}\text { Male Fischer } 344 \\
\text { rats }\end{array}$ & Not reported & Not reported & $\begin{array}{l}\text { Hepcidin mRNA } \\
\text { significantly and } \\
\text { progressively } \\
\text { increased from } \\
2 \text { to } 8 \text { hours after } \\
\mathrm{PH} \text {; lower than } \\
\text { in the sham- } \\
\text { operated-on } \\
\text { group at } 72 \text { hours } \\
\text { and } 1 \text { week }\end{array}$ & $\begin{array}{l}\text { Serum iron } \\
\text { significantly } \\
\text { lower in both } \\
\text { the PH and } \\
\text { sham-operated- } \\
\text { on group for } 24 \\
\text { hours after } \\
\text { intervention }\end{array}$ & 50 \\
\hline $\begin{array}{l}\text { Selective liver } \\
\text { irradiation (I- } \\
\text { R; } 25 \text { Gy } \times 1 \text { ) }\end{array}$ & Male Wistar rats & Not reported & Not reported & $\begin{array}{l}\text { Hepcidin mRNA } \\
\text { significantly } \\
\text { increased } \\
\text { (29-fold) } 24 \\
\text { hours after I-R }\end{array}$ & $\begin{array}{l}\text { Trend for a decrease } \\
\text { in serum iron } \\
\text { levels after I-R; } \\
\text { serum } \\
\text { prohepcidin } \\
\text { levels increased } \\
\text { significantly } \\
\text { (twofold) } \\
\text { after I-R }\end{array}$ & 52 \\
\hline $\begin{array}{l}\text { Acetaminophen } \\
\text { toxicity ( } 300 \\
\mathrm{mg} / \mathrm{kg} \text { body } \\
\text { weight) }\end{array}$ & $\begin{array}{l}\text { Male and female } \\
\text { C57BL/6N mice }\end{array}$ & Centrilobular necrosis & Not reported & $\begin{array}{l}\text { Hepcidin mRNA } \\
\text { unchanged vs } \\
\text { controls; serum } \\
\text { hepcidin } \\
\text { significantly } \\
\text { decreased in } \\
\text { acetaminophen- } \\
\text { treated mice }\end{array}$ & & 53 \\
\hline
\end{tabular}

$\mathrm{CCl}_{4}$, carbon tetrachloride; I-R, ischemia-reperfusion; $\mathrm{PH}$, partial hepatectomy. 
irradiation. Serum iron levels tended to decrease after irradiation, but the difference between the irradiated animals and controls was not statistically significant. Serum prohepcidin levels increased significantly 3 hours after irradiation before returning to control levels at 6 hours and subsequently. Notably, this increase preceded the increase in Hamp mRNA.

In contrast to the models discussed above, Spivak et $\mathrm{al}^{53}$ found that Hamp mRNA levels in mice were unchanged 18 hours after acetaminophen overdose. It is difficult to compare these results directly with the other acute injury models discussed above because in the latter cases hepcidin expression generally peaked early ( $\leq 12$ hours) after injury, in some instances returning to baseline or below by 18 hours. Despite the lack of change in Hamp mRNA levels, serum hepcidin in the acetaminophen-treated group was approximately half that of the control group, and serum iron levels were approximately $40 \%$ higher.

These studies demonstrate that acute liver injury is often associated with transient increases in hepcidin expression (Figure 1). In some models, increases in Hamp mRNA levels were preceded by elevations in inflammatory mediators, such as IL-6, suggesting that induction of hepcidin in these circumstances typifies its behavior as an acute-phase

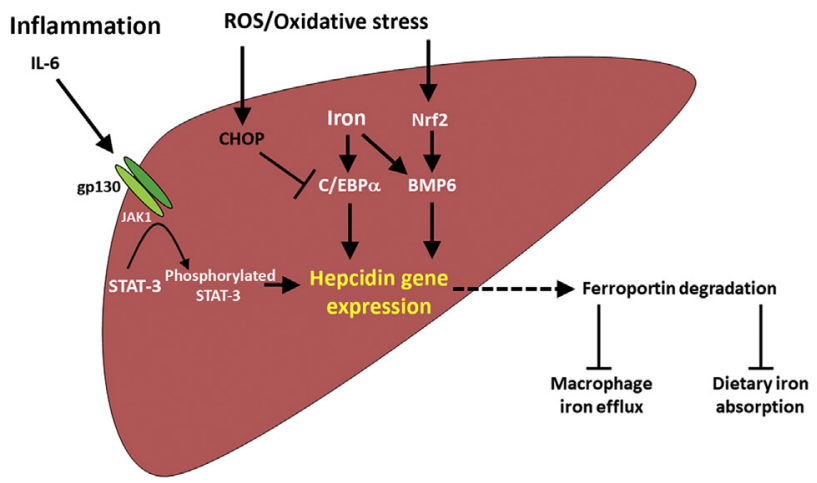

Figure 1 Factors involved in the regulation of hepatic hepcidin expression in response to liver injury. In several forms of acute liver injury, hepcidin expression is upregulated via activation of STAT3 driven by inflammatory cytokines, in particular IL-6. Hypoferremia is commonly reported in these models and is presumed to be at least in part due to increased secretion of hepcidin, leading to enhanced degradation of the iron transporter ferroportin, which results in diminished iron efflux from macrophages and enterocytes. In contrast, Hamp mRNA is downregulated in a number of models of chronic liver injury. In some cases, this has been linked to oxidative stress-mediated upregulation of CCAAT enhancerbinding protein homologous protein (CHOP). CHOP inhibits the DNAbinding activity of CCAAT enhancer-binding protein $\alpha(C / E B P \alpha)$, the major transcription factor governing hepcidin expression. 0xidative stress can also upregulate hepcidin by means of enhanced expression of bone morphogenetic protein 6 (BMP6), but the relevance of this to liver injury models has not been assessed. Although decreases in Hamp mRNA are commonly seen in models of chronic liver injury, effects on iron status are inconsistent for reasons that are currently unknown. gp130, glycoprotein 130; Nrf2, nuclear factor erythroid-2-related factor 2; ROS, reactive oxygen species. reactant. ${ }^{49,51,52}$ In keeping with this interpretation, most of the models discussed here are characterized by hypoferremia. However, the frequent instances in which hypoferremia was observed to precede increases in Hamp mRNA and/or to occur in the absence of measurable increases in circulating hepcidin levels, as described above, suggests that additional factors are involved in regulating iron levels in these acute-phase models.

\section{Models of Alcoholic and Nonalcoholic Fatty Liver Disease}

Alcoholic liver disease in humans is frequently accompanied by evidence of dysregulated iron metabolism. Accordingly, a number of experiments have been performed in an attempt to reproduce this phenomenon (Table 2) ${ }^{54-61}$ From these studies, considerable evidence has accumulated showing that relatively short-term exposure to alcohol suppresses hepcidin expression in rodents. Bridle et $\mathrm{al}^{54}$ were the first to report a marked reduction in Hamp mRNA levels in rats fed a liquid diet that contained ethanol for 12 weeks. Shortly thereafter, Harrison-Findik et $\mathrm{al}^{55}$ found that ingestion of $20 \%$ ethanol in the drinking water for 7 days potently suppressed hepcidin expression in mice; Ohtake et $\mathrm{al}^{56}$ made similar observations in mice after only 4 days of ethanol gavage. Both Bridle et $\mathrm{al}^{54}$ and Harrison-Findik et $\mathrm{al}^{55}$ implicated downregulation of $\mathrm{C} / \mathrm{EBP} \alpha$ in ethanol-mediated suppression of hepcidin expression, with the former observing that $\mathrm{C} / \mathrm{EBP} \alpha \mathrm{mRNA}$ was significantly decreased in ethanoltreated rat livers, ${ }^{54}$ whereas the latter demonstrated that $\mathrm{C} / \mathrm{EBP} \alpha$ DNA-binding activity and protein levels were reduced in livers of mice exposed to ethanol. ${ }^{55}$ HarrisonFindik et $\mathrm{al}^{55}$ also found that vitamin $\mathrm{E}$ reversed the suppression of $\mathrm{C} / \mathrm{EBP} \alpha$-binding activity and restored hepcidin expression in ethanol-treated mice, suggesting that oxidative stress was involved in the suppression of hepcidin by ethanol. ${ }^{55}$ Additional support for this concept was provided by Tang et al, ${ }^{57}$ who observed that coadministration of the flavonoid antioxidant quercetin with an ethanol-containing liquid diet prevented the modest suppression of Hamp, Bmp6, and Smad4 mRNAs in mouse liver. Notably, however, oxidative stress in these models occurred in the absence of significant histologic liver injury apart from steatosis in some cases. ${ }^{54,55,57}$

In contrast to the rapid changes in hepcidin expression described above, Heritage et $\mathrm{al}^{58}$ found a significant reduction in Hamp mRNA after only 4 weeks of ethanol in a murine model. However, its mechanism was not identified because phosphorylated STAT3 was increased by ethanol, whereas $\mathrm{C} / \mathrm{EBP} \alpha$ was unchanged. Additional variability in this phenomenon was noted in a study ${ }^{59}$ that showed that $20 \%$ ethanol in drinking water for 14 days decreased Hamp mRNA in $129 \times 1 / \mathrm{SvJ}$ mice but not in mice of the C57BL/6 or AKR/J strains. ${ }^{59}$ Because the studies by Ohtake et al, ${ }^{56}$ Tang et $\mathrm{al}^{57}$ and Heritage et $\mathrm{al}^{58}$ all used $\mathrm{C} 57 \mathrm{BL} / 6$ 
Table 2 Effects of Alcohol and Nonalcoholic Fatty Liver on Hepcidin and Iron Metabolism

\begin{tabular}{|c|c|c|c|c|c|c|}
\hline Model & $\begin{array}{l}\text { Experimental } \\
\text { animal }\end{array}$ & $\begin{array}{l}\text { Effect on liver } \\
\text { histologic findings }\end{array}$ & $\begin{array}{l}\text { Effect on hepatic } \\
\text { iron content }\end{array}$ & $\begin{array}{l}\text { Effect on } \\
\text { hepcidin }\end{array}$ & Comments & Reference \\
\hline $\begin{array}{l}\text { Lieber-DeCarli diet } \\
\text { (ethanol: } 36 \% \text { of } \\
\text { calories) } \times 12 \mathrm{wk}\end{array}$ & $\begin{array}{l}\text { Male Sprague- } \\
\text { Dawley rats }\end{array}$ & $\begin{array}{l}\text { Macrovesicular } \\
\text { steatosis }\end{array}$ & $\begin{array}{l}\text { No difference } \\
\text { between ethanol- } \\
\text { treated and } \\
\text { control }\end{array}$ & $\begin{array}{l}\text { Sixfold decrease } \\
\text { in hepcidin } \\
\text { mRNA in } \\
\text { ethanol- } \\
\text { treated livers }\end{array}$ & $\begin{array}{l}\text { Hepatic C/EBP } \alpha \\
\text { mRNA decreased in } \\
\text { ethanol-treated } \\
\text { livers }\end{array}$ & 54 \\
\hline $\begin{array}{l}\text { Ethanol gavage } \\
\text { every } \\
12 \text { hours } \times 4 \mathrm{~d} \text {, } \\
\text { dose varying from } \\
5 \text { to } 10 \mathrm{~g} / \mathrm{kg}\end{array}$ & Male $\mathrm{C} 57 \mathrm{BL} / 6$ mice & $\begin{array}{l}\text { Mild steatosis, no } \\
\text { stainable iron }\end{array}$ & Not reported & $\begin{array}{l}\text { Significant } \\
\text { reduction in } \\
\text { hepcidin } \\
\text { mRNA }\end{array}$ & & 56 \\
\hline $\begin{array}{l}\text { Lieber-DeCarli diet } \\
\text { (ethanol: } 21 \% \text { of } \\
\text { calories) } \times 8 \mathrm{wk}\end{array}$ & Male C57BL/6 mice & $\begin{array}{l}\text { Macrovesicular } \\
\text { steatosis, no } \\
\text { stainable iron }\end{array}$ & $\begin{array}{l}\text { No difference } \\
\text { between ethanol- } \\
\text { treated and } \\
\text { control }\end{array}$ & $\begin{array}{l}\text { Significant } \\
\text { reduction in } \\
\text { hepcidin } \\
\text { mRNA at } 4 \mathrm{wk}\end{array}$ & $\begin{array}{l}\text { Levels of C/EBP } \alpha \text { and } \\
\text { phosphorylated C/ } \\
\text { EBP } \alpha \text { not altered } \\
\text { by ethanol }\end{array}$ & 58 \\
\hline $\begin{array}{l}\text { Ethanol }(20 \%) \text { in } \\
\text { drinking water } \\
\times 14 \mathrm{~d}\end{array}$ & $\begin{array}{r}129 \times 1 / \mathrm{C} 57 \mathrm{BL} / 6 \\
\text { and } \mathrm{AKR} / \mathrm{J} \text { mice }\end{array}$ & Not reported & $\begin{array}{l}\text { No difference } \\
\text { between ethanol- } \\
\text { treated and } \\
\text { control in any } \\
\text { strain }\end{array}$ & $\begin{array}{l}\text { Significant } \\
\text { decrease in } \\
\text { hepcidin } \\
\text { mRNA only in } \\
\text { ethanol- } \\
\text { treated } \\
129 \times 1 / \text { SvJ }\end{array}$ & & 59 \\
\hline $\begin{array}{l}\text { Ethanol }(10 \% \\
-20 \%) \text { in } \\
\text { drinking water for } \\
42-44 \text { wk }\end{array}$ & $\begin{array}{l}\text { Female } \mathrm{C} 57 \mathrm{BL} / 6 \\
\mathrm{BALB} / \mathrm{c} \text { mice }\end{array}$ & $\begin{array}{l}\text { Mild steatosis, mild } \\
\text { increase in } \\
\text { stainable iron }\end{array}$ & $\begin{array}{l}\text { Significant increase } \\
\text { in ethanol- } \\
\text { treated } \mathrm{C} 57 \mathrm{BL} / 6 \text {; } \\
\text { NS in BALB/C }\end{array}$ & $\begin{array}{l}\text { No change in } \\
\text { hepcidin } \\
\text { mRNA }\end{array}$ & $\begin{array}{l}\text { Expression of several } \\
\text { oxidative stress- } \\
\text { responsive } \\
\text { transcripts } \\
\text { unaltered by } \\
\text { ethanol }\end{array}$ & 61 \\
\hline $\mathrm{HF} / \mathrm{HE} \times 6 \mathrm{wk}$ & Male Wistar rats & $\begin{array}{l}\text { Not reported; livers } \\
\text { of rats fed HF/HE } \\
\text { diet with } \\
\text { macroscopic } \\
\text { steatosis }\end{array}$ & $\begin{array}{l}\text { Trend toward } \\
\text { reduction in HF/ } \\
\text { HE group but not } \\
\text { significant }\end{array}$ & $\begin{array}{l}\text { Hepcidin mRNA } \\
\text { significantly } \\
\text { lower in HF/ } \\
\text { HE group }\end{array}$ & $\begin{array}{l}\text { Spleen iron } \\
\text { significantly lower } \\
\text { in HF/HE group; } \\
\text { hemoglobin and } \\
\text { plasma transferrin } \\
\text { higher in HF/HE } \\
\text { group, transferrin } \\
\text { saturation reduced } \\
\text { vs controls }\end{array}$ & 62 \\
\hline $\mathrm{HFD} \times 16 \mathrm{wk}$ & Male $\mathrm{C} 57 \mathrm{BL} / 6$ mice & Not reported & $\begin{array}{l}\text { Significant } \\
\text { reduction in HFD } \\
(<50 \% \text { of } \\
\text { control })\end{array}$ & $\begin{array}{l}\text { Significant } \\
\text { reduction in } \\
\text { HFD group } \\
(<50 \% \text { of } \\
\text { control) }\end{array}$ & $\begin{array}{l}\text { Serum amyloid A } \\
\text { levels significantly } \\
\text { increased in HFD } \\
\text { experimental and } \\
\text { control group }\end{array}$ & 63 \\
\hline
\end{tabular}

(table continues) 
Table 2 (continued)

\begin{tabular}{|c|c|c|c|c|c|c|}
\hline Model & $\begin{array}{l}\text { Experimental } \\
\text { animal }\end{array}$ & $\begin{array}{l}\text { Effect on liver } \\
\text { histologic findings }\end{array}$ & $\begin{array}{l}\text { Effect on hepatic } \\
\text { iron content }\end{array}$ & $\begin{array}{l}\text { Effect on } \\
\text { hepcidin }\end{array}$ & Comments & Reference \\
\hline $\mathrm{HFD} \times 8 \mathrm{wk}$ & Male $\mathrm{C} 57 \mathrm{BL} / \mathrm{b}$ mice & $\begin{array}{l}\text { Steatosis; no } \\
\text { stainable iron }\end{array}$ & $\begin{array}{l}\text { Not different from } \\
\text { control }\end{array}$ & $\begin{array}{l}\text { Nonsignificant } \\
\text { decrease in } \\
\text { hepcidin } \\
\text { mRNA and } \\
\text { serum } \\
\text { hepcidin in } \\
\text { HFD group }\end{array}$ & $\begin{array}{l}\text { Plasma iron, } \\
\text { intestinal iron } \\
\text { absorption lower in } \\
\text { HFD group; } \\
\text { hemoglobin, RBC } \\
\text { counts, and splenic } \\
\text { iron content } \\
\text { unchanged }\end{array}$ & 64 \\
\hline $\mathrm{HFD} \times 12 w k$ & Male $\mathrm{C} 57 \mathrm{BL} / 6$ mice & $\begin{array}{l}\text { Steatosis in HFD } \\
\text { group; stainable } \\
\text { iron not assessed }\end{array}$ & $\begin{array}{l}\text { Significant } \\
\text { decrease in HFD } \\
\text { ( } 44 \% \text { of control } \\
\text { value) }\end{array}$ & $\begin{array}{l}\text { Hepcidin mRNA } \\
\text { levels } \\
\text { decreased by } \\
60 \% \text { in HFD } \\
\text { group }\end{array}$ & $\begin{array}{l}\text { Modest but } \\
\text { significant } \\
\text { decrease in } \\
\text { transferrin } \\
\text { saturation in HFD } \\
\text { group; hepatic } \\
\text { TFR1 protein levels } \\
\text { increased in HFD } \\
\text { group }\end{array}$ & 65 \\
\hline$A D \times 6$ or $18 w k$ & $\begin{array}{l}\text { Female } \mathrm{C} 57 \mathrm{BL} / 6 \\
\mathrm{BALB} / \mathrm{C} \\
\mathrm{C} 3 \mathrm{H} / \mathrm{HeJ} \text { mice }\end{array}$ & $\begin{array}{l}\text { Steatosis, } \\
\text { inflammation of } \\
\text { varying severity } \\
\text { in AD-fed mice; } \\
\text { no stainable iron }\end{array}$ & $\begin{array}{l}\text { Decreased by } A D \text { in } \\
\text { all strains at both } \\
\text { time points }\end{array}$ & $\begin{array}{l}\text { No differences } \\
\text { in hepcidin } \\
\text { mRNA with AD } \\
\text { at } 6 \text { wk; } \\
\text { significantly } \\
\text { decreased in } \\
\text { AD-fed } \\
\text { C57BL/6 mice } \\
\text { and increased } \\
\text { in BALB/c vs } \\
\text { controls at } 18 \\
\text { wk }\end{array}$ & & 66 \\
\hline $\begin{array}{l}\text { High-fat, high- } \\
\text { fructose diet for } \\
\text { up to } 16 \mathrm{wk}\end{array}$ & $\begin{array}{l}\text { Male } \mathrm{C} 57 \mathrm{BL} / 6 \mathrm{~J} \\
\text { mice }\end{array}$ & $\begin{array}{l}\text { Mild steatosis in } \\
\text { HFD at week 4, } \\
\text { increasing to } \\
\text { week 16; } \\
\text { stainable iron } \\
\text { not assessed }\end{array}$ & $\begin{array}{l}\text { Significant increase } \\
\text { in HFD at weeks } 2 \\
-12 ; \text { not } \\
\text { different from } \\
\text { control at week } \\
16\end{array}$ & $\begin{array}{l}\text { Hepcidin mRNA } \\
\text { assessed only } \\
\text { at weeks } 2 \\
\text { and } 8 \text {; no } \\
\text { difference } \\
\text { between HFD } \\
\text { group and } \\
\text { controls at } \\
\text { week 2; } \\
\text { significant } \\
\text { reduction in } \\
\text { HFD at week } 8\end{array}$ & $\begin{array}{l}\text { Hepcidin mRNA } \\
\text { increased eightfold } \\
\text { in controls } \\
\text { between weeks } 2 \\
-8 ; \text { hepcidin } \\
\text { mRNA in } \\
\text { experimental group } \\
\text { doubled in the } \\
\text { same interval; no } \\
\text { data on hepcidin } \\
\text { mRNA at } 16 \text { weeks } \\
\text { when HICs were } \\
\text { similar between } \\
\text { experimental and } \\
\text { control group }\end{array}$ & 68 \\
\hline
\end{tabular}

$A D$, atherogenic diet; BMP6, bone morphogenetic protein; $C / E B P \alpha, C C A A T$ enhancer-binding protein $\alpha$; HFD, high-fat diet; HFHE, high-fat, high-energy diet; HICs, hepatic iron concentrations; NS, non-significant; RBC, red blood cell; TFR1, transferrin receptor 1. 
Table 3 Effects of Chronic Liver Injury Models on Hepcidin and Iron Metabolism

\begin{tabular}{|c|c|c|c|c|c|c|}
\hline Model & $\begin{array}{l}\text { Experimental } \\
\text { animal }\end{array}$ & $\begin{array}{l}\text { Effect on liver } \\
\text { histologic findings }\end{array}$ & $\begin{array}{l}\text { Effect on hepatic } \\
\text { iron content }\end{array}$ & Effect on hepcidin & Comments & Reference \\
\hline $\begin{array}{l}\text { Transgenic mice } \\
\text { expressing full- } \\
\text { length HCV } \\
\text { polyprotein }\end{array}$ & Male $\mathrm{C} 57 \mathrm{BL} / 6$ mice & $\begin{array}{l}\text { Increased stainable } \\
\text { iron; no } \\
\text { inflammation }\end{array}$ & $\begin{array}{l}\text { Increased } 30 \% \\
-40 \% \text { vs non- } \\
\text { transgenic mice } \\
\text { at } 8 \text { and } 14 \text { mo of } \\
\text { age }\end{array}$ & $\begin{array}{l}\text { Stable reduction of } \\
\text { approximately } \\
30 \% \text { in hepcidin } \\
\text { mRNA and } \\
\text { hepatic } \\
\text { prohepcidin at } 8 \\
\text { and } 14 \text { mo }\end{array}$ & $\begin{array}{l}\text { Decreased C/EBP } \alpha \\
\text { DNA-binding } \\
\text { activity linked to } \\
\text { increased CHOP, } \\
\text { increased ROS }\end{array}$ & 73 \\
\hline BDL & $\begin{array}{c}\text { Male Sprague- } \\
\text { Dawley rats }\end{array}$ & $\begin{array}{l}\text { Iron-laden } \\
\text { macrophages in } \\
\text { areas of necrosis } \\
\text { in BDL livers }\end{array}$ & Not reported & $\begin{array}{l}\text { Hepcidin mRNA } \\
\text { livers decreased } \\
\text { by } 6 \text { hours after } \\
\text { BDL, remained } \\
\text { significantly } \\
\text { lower for at least } \\
2 \text { wk }\end{array}$ & $\begin{array}{l}\text { Decreased gp130 } \\
\text { mRNA and } \\
\text { phosphorylated } \\
\text { STAT3 protein } \\
\text { and nuclear } \\
\text { translocation } \\
\text { after BDL }\end{array}$ & 74 \\
\hline $\begin{array}{l}\text { Hereditary } \\
\text { tyrosinemia type } \\
1 \text { model (Fah }{ }^{-/-} \\
\text {mouse) }\end{array}$ & 129/SvEvTac mice & $\begin{array}{l}\text { Patchy increase in } \\
\text { iron staining }\end{array}$ & $\begin{array}{l}\text { Significant increase } \\
\text { in } \mathrm{Fah}^{-/-} \text {versus } \\
\text { control }\end{array}$ & $\begin{array}{l}\text { Significant } \\
\text { reduction in } \\
\text { hepcidin mRNA } \\
\text { in } \mathrm{Fah}^{-/} \text {preceded } \\
\text { increase in HICs }\end{array}$ & $\begin{array}{l}\text { Reduction in } \\
\text { hepcidin mRNA } \\
\text { mediated in part } \\
\text { by decreased } \\
\text { TFR2 expression }\end{array}$ & 76 \\
\hline $\begin{array}{l}\mathrm{TAA} \text { or } \mathrm{CCl}_{4} \text { i.p. } \\
\text { twice a wk for } 8 \\
\text { wk }\end{array}$ & Male Albino rats & Not reported & Not reported & $\begin{array}{l}\text { Hepcidin mRNA } \\
\text { levels } \\
\text { significantly } \\
\text { decreased in TAA } \\
\text { group, } \\
\text { significantly } \\
\text { increased in } \mathrm{CCl}_{4}\end{array}$ & $\begin{array}{l}\text { Hemoglobin, serum } \\
\text { iron, transferrin } \\
\text { saturation } \\
\text { significantly } \\
\text { decreased in } \mathrm{CCl}_{4}\end{array}$ & 78 \\
\hline
\end{tabular}

$\mathrm{BDL}$, bile duct ligation; BMP6, bone morphogenetic protein; $\mathrm{CCl}_{4}$, carbon tetrachloride; $\mathrm{C} / \mathrm{EBP} \alpha, \mathrm{CCAAT}$ enhancer-binding protein $\alpha ; \mathrm{CHOP}, \mathrm{CCAAT}$ enhancerbinding protein homologous protein; gp130, glycoprotein 130; HCV, hepatitis C virus; HICs, hepatic iron concentrations; IVC, inferior vena cava; RBC, red blood cell; ROS, reactive oxygen species; TAA, thioacetamide; TFR2, transferrin receptor 2.

mice ${ }^{56-58}$ the reason for these variable results is not known, although it is possible that the specifics of the ethanol regimen and duration of treatment may be important variables.

These data suggest that downregulation of hepcidin expression by alcohol ingestion may be linked to dysregulated iron metabolism in humans with alcoholic liver disease, but there are caveats regarding this conclusion. First, few investigations have addressed ethanol-induced alterations in hepcidin expression within the larger context of iron metabolism. An exception is a study from Varghese et $\mathrm{al}^{60}$ in which mice ingesting an ethanolcontaining liquid diet were examined at 2, 4, 8, and 12 weeks. These investigators found that Hamp mRNA and 
serum levels were downregulated after only 12 weeks of ethanol consumption. At that same timepoint, hepatic iron and ferritin levels were significantly lower in ethanol-fed mice, whereas duodenal ferroportin protein and serum iron levels were elevated versus controls. Although these data suggest that the ethanol-mediated reduction in hepatic iron may be the initial event that triggers the subsequent alterations, the mechanism for the decrease in liver iron in response to ethanol remains obscure. It is likewise unclear why TFR1 levels were lower in the livers of the ethanol-fed animals despite the reduction in iron stores.

Second, the lack of iron accumulation in response to suppression of hepcidin in these models has not been adequately explained. The studies Bridle et al, ${ }^{54}$ Heritage et $\mathrm{al}^{58}$ and Flanagan et $\mathrm{al}^{59}$ found no change in hepatic iron concentrations (HICs) resulting from ethanol treatment; HICs were not assessed in the short-term experiments of Harrison-Findik et $\mathrm{al}^{55}$ and Ohtake et al. ${ }^{56}$ Data regarding intestinal iron uptake in these models are scarce, but Flanagan et $\mathrm{al}^{59}$ found no effect of ethanol on iron absorption, even in the strain in which Hamp mRNA was downregulated by ethanol. ${ }^{59}$ These results are unsurprising in light of experiments performed decades before the discovery of hepcidin that found no effect of ethanol on hepatic iron content in rodents. ${ }^{69-71}$ Nonetheless, the reproducible reduction in Hamp mRNA without an obvious effect on liver iron content in these models is perplexing. Some authors have proposed that iron does not increase in these models because hepatic iron accumulation is a slow process. This rationale is based on an analogy with $H F E$-linked $\mathrm{HH}$, in which iron increases incrementally as a result of the relatively modest effect of $H F E$ mutations on HAMP expression. However, the reductions in Hamp mRNA in some of these models are large, and one might reasonably predict that they would have greater effects on iron absorption than do the HFE mutations. In any event, the assumption that, given sufficient time, ethanol-mediated suppression of hepcidin would lead to hepatic iron accumulation in these models needs to be verified experimentally. In one of the few long-term studies on this topic, Bloomer et $\mathrm{al}^{61}$ observed modest increases in HICs with no change in Hamp mRNA levels in mice consuming ethanol in their drinking water for $>10$ months. There was no histologic inflammation or evidence of oxidative stress in the livers of the ethanol-treated mice in this study; thus, additional research is needed to clarify the mechanism of ethanol-induced alterations in iron metabolism in this model.

NAFLD is another common condition associated with dysregulated iron metabolism. Similar to ethanol treatment, downregulation of hepcidin expression has been observed in several rodent models of fatty liver (Table 2) ${ }^{62-68}$; however, in some instances, this downregulation has occurred in the context of decreased hepatic iron stores and/or increased iron utilization. In the first study examining this question, Le Guenno et $\mathrm{al}^{62}$ fed rats a high-fat/high-energy (HFHE) diet to create a state of insulin resistance, which is commonly associated with NAFLD. Although liver histologic findings were not reported this study, the livers of animals on the HFHE diet were described as macroscopically steatotic, and both hepatic and splenic iron content decreased in the HFHEfed rats. Hamp mRNA levels decreased significantly in the livers of animals fed the HFHE diet at the same time that their hemoglobin concentrations were higher and transferrin saturations lower. Taken together, these findings suggest that the reduction in hepcidin expression was a response to increased iron utilization resulting from enhanced erythropoiesis. Similarly, Chung et $\mathrm{al}^{63}$ observed reductions in both Hamp mRNA and HICs in mice fed a high-fat diet (HFD) for 16 weeks. In that study, the HFD was associated with an inflammatory response, as shown by elevated levels of the major murine acute-phase reactant serum amyloid A in the HFD-fed mice. The authors noted that despite the reduction in Hamp mRNA compared with controls, hepcidin transcript levels were high relative to the iron stores of the HFD mice, presumably because its expression was driven by inflammation.

Likewise, Sonnweber et $\mathrm{al}^{64}$ found that Hamp mRNA levels were reduced in mice fed a HFD for 8 weeks, but they observed no change in hepatic iron or hemoglobin concentrations. These investigators demonstrated that both intestinal iron absorption and plasma iron levels were decreased with the HFD. Furthermore, the addition of dietary carbonyl iron failed to augment HICs in mice fed the HFD versus a nearly threefold elevation in mice fed the standard diet with carbonyl iron, reinforcing the conclusion that the HFD impaired intestinal iron uptake. The authors proposed that the net effect of the HFD was to cause systemic iron deficiency, which suggests that HICs in the HFDfed mice might have decreased had the experiment been performed for a longer period. The early reduction in Hamp mRNA may thus represent a response to low plasma iron, but the mechanism initiating this cascade of events (ie, reduced iron absorption) was not identified in this study. Moreover, the reduction in intestinal iron uptake in the face of decreased hepcidin expression implies either a disjunction between the level of hepcidin transcripts and its biological activity or the existence of a mechanism for modulation of iron uptake that supersedes or opposes the effects of hepcidin.

Similar to the work discussed above, Padda et $\mathrm{al}^{65}$ found that mice fed a HFD for 12 weeks exhibited hypoferremia, decreases in transferrin saturation and HICs, and increases in TFR1 levels. Together with the observed reduction in hepcidin expression, these findings indicate that the HFD resulted in a state of iron deficiency. Contrary to the findings of Sonnweber et al, ${ }^{64}$ these authors reported that supplementation of the HFD with carbonyl iron resulted in increases in serum iron, transferrin saturation, and HICs and 
reduced TFR1 levels. The reason for the differing outcomes of these experiments is not clear.

In a different model of fatty liver, Bloomer et $\mathrm{al}^{66}$ reported that an atherogenic diet decreased HICs in three different strains of mice after 6 weeks; this difference was less prominent after 18 weeks on the atherogenic diet, but the change in HICs was not accompanied by significant alterations in Hamp mRNA at either time point. In addition to steatosis, this model elicits an inflammatory response of variable intensity in the different strains, but no correlation was observed between hepcidin and markers of inflammation in any of the strains.

The models discussed above suggest that inflammation modulates the effects of steatosis on hepatic iron metabolism. A recent study from Varghese et $\mathrm{al}^{67}$ demonstrated that fatty liver per se alters liver iron content and hepcidin expression in the absence of an inflammatory response. These investigators examined the effects of an HFD on iron homeostasis in mice at multiple timepoints and found that HICs were reduced at 16 weeks, followed by decreased Hamp mRNA and serum levels at 24 weeks in the mice fed the HFD. Markers of inflammation (serum C-reactive protein and hepatic expression of serum amyloid A and IL-6) were unaltered at all timepoints in the mice fed the HFD. These data suggest that the reduction in hepcidin expression in the HFD-fed mice was a physiologic response to the change in liver iron stores, but the reason for the latter remains obscure.

The findings ${ }^{68}$ in a model of insulin resistance elicited by a high-fat, high-fructose (HFHFr) diet stand in contrast to the studies discussed above. Despite lower dietary iron intake (resulting from the lower iron content of the HFHFr diet and reduced intake), HICs were modestly elevated at 2 , 4,8 , and 12 weeks on the HFHFr diet but similar to control levels at 16 weeks. Hamp mRNA levels did not differ between HFHFr-fed mice and controls at 2 weeks; thus, the increase in HICs was not preceded by an alteration in hepcidin expression. Although hepcidin transcript levels were significantly lower in the HFHFr mice versus controls at 8 weeks, this finding was driven by a large increase in Hamp mRNA in the control mice between weeks 2 and 8 , which was itself independent of a major change in HICs in that group, making the changes in hepcidin expression levels difficult to interpret.

Taken together, reductions in Hamp mRNA and hepatic iron content are observed in different models of fatty liver, several of which are associated with evidence of iron deficiency. In some cases, the effects of fatty liver on hepcidin appear to be modulated by inflammatory responses, but most of these reports lack data on inflammation and few assessed oxidative stress. Although generally uninformative with respect to the mechanisms leading to elevated iron markers and hepatic iron accumulation in NAFLD, these models may be useful to study the pathogenesis of iron deficiency in fatty liver, which is common, especially in patients with morbid obesity. ${ }^{72}$

\section{Other Models of Chronic Liver Injury}

Effects of several other forms of chronic liver injury on hepcidin and iron metabolism have been reported (Table 3). ${ }^{73-78}$ Nishina et $\mathrm{al}^{73}$ studied the effects of hepatitis $\mathrm{C}$ infection on iron metabolism using a transgenic mouse expressing the full-length hepatitis $\mathrm{C}$ polyprotein coding region under the control of the albumin promoter. Although the presence of the transgene did not result in hepatic inflammation or other histologic signs of injury, Hamp mRNA and prohepcidin were reduced by approximately $30 \%$ in the livers of transgenic mice versus nontransgenic controls at 8 and 14 months of age, and these changes were accompanied by an increase in liver iron content of comparable magnitude. The decrease in hepcidin expression in the livers of transgenic mice was associated with diminished DNA-binding activity of $\mathrm{C} / \mathrm{EBP} \alpha$; this diminished activity was attributed to an increase in CHOP, which in turn was linked to higher levels of reactive oxygen species production. Whether suppression of reactive oxygen species production was able to reverse or mitigate this series of events was not reported.

In a model of cholestatic liver injury, ${ }^{74}$ hepcidin expression decreased significantly 3 days and 2 weeks after bile duct ligation (BDL), whereas plasma hepcidin levels decreased as early as 6 hours after BDL. Although hepatic IL6 mRNA levels were increased, expression of gp130 (the IL-6 receptor) and phosphorylated STAT3 immunoreactivity were reduced after BDL, likely accounting for the decrease in hepcidin expression. Despite the reduction in Hamp mRNA, stainable iron in the BDL rats was localized to macrophages. Because low hepcidin favors mobilization of iron from macrophages, this finding may represent iron accumulation resulting from the ingestion of necrotic cells by macrophages. These authors also found that HAMP mRNA levels were significantly lower than controls in a small group of patients with chronic cholestatic liver disease. Interestingly, this finding was not associated with an increase in hepatic iron content, which is consistent with other studies that have found that secondary iron overload is less common in cholestatic liver disease than in other forms of chronic liver disease in humans. ${ }^{79}$

Suzuki et $\mathrm{al}^{75}$ used inferior vena cava (IVC) ligation to evaluate the effects of hepatic congestion on iron metabolism. Hemoglobin levels decreased sharply in IVC-ligated rats 1 week after surgery but gradually increased during the next 11 weeks. Despite the improvement, hemoglobin levels remained significantly lower in the IVC-ligated animals where it was accompanied by signs of iron deficiency (microcytosis and decreased serum iron and transferrin saturation). Although Hamp mRNA levels in the IVCligated animals were higher than in rats with similar degrees of anemia resulting from phlebotomy or phenylhydrazine-induced hemolysis, serum hepcidin levels were elevated in the IVC-ligated rats only on day 4. Hepatic iron content was not evaluated quantitatively, but iron stains 
highlighted hemosiderin-laden macrophages. Hepatic Bmp6 and IL6 mRNA and serum IL-6 levels were significantly increased in the IVC-ligated rats versus controls, presumably accounting for the persistent increase in hepcidin expression. These findings suggest that this model of congestive hepatopathy reproduces features of anemia of chronic inflammation or chronic disease.

Bao et $\mathrm{al}^{76}$ studied iron metabolism in Fah knockout mice, a model of hereditary tyrosinemia type 1 . $\mathrm{Fah}^{-/-}$mice treated with 2-(2-nitro-4-trifluoromethylbenzoyl)-1,3cyclohexanedione (NTBC), a drug that blocks tyrosine catabolism upstream of fumarylacetoacetate hydrolase, have prolonged liver injury-free survival; withdrawal of NTBC leads to development of phenotypic manifestations of tyrosinemia. In $\mathrm{Fah}^{-/}$mice, Hamp mRNA levels decreased significantly 1 week after withdrawal of NTBC; liver iron content doubled at 3 weeks and more than tripled at 5 weeks after NTBC withdrawal compared with animals maintained on NTBC. Notably, the reduction in hepcidin expression preceded overt manifestations of liver injury, such as elevated aminotransferases and increased hepatocyte apoptosis. These authors found that TfR2 expression decreased in $\mathrm{Fah}^{-/}$mice withdrawn from NTBC with a time course similar to that of Hamp; administration of a TfR2overexpressing adenovirus to $\mathrm{Fah}^{-/-}$mice rescued hepcidin expression and mitigated but did not completely prevent iron accumulation.

Thioacetamide (TAA) and $\mathrm{CCl}_{4}$ are commonly used to induce hepatic fibrosis in rodents. The contrasting effects of repeated administration of these agents on iron metabolism have been addressed in 2 studies. ${ }^{77,78}$ Mueller et al ${ }^{77}$ were the first to report that long-term TAA treatment resulted in a modest decrease in Hamp transcripts with a larger decrement in hepatic prohepcidin and an approximately twofold elevation in hepatic iron content. In contrast, iron content, Hamp mRNA, and protein were unaffected by long-term $\mathrm{CCl}_{4}$ treatment despite comparable stages of hepatic fibrosis to the TAA-treated mice. In both models, macrophages were the predominant site of iron deposition with mild hepatocellular iron seen in the TAA model. The reduction in hepcidin expression in TAA livers was associated with greatly diminished binding of $\mathrm{C} / \mathrm{EBP} \alpha$ to the hepcidin promoter in extracts from TAA livers compared with $\mathrm{CCl}_{4}$-treated livers, an effect attributed to the higher levels of CHOP in the former. Notably, IL6 expression was unaffected by TAA but robustly increased by $\mathrm{CCl}_{4}$ treatment.

The latter finding was confirmed in another study comparing these agents. Gheith and El-Mahmoudy ${ }^{78}$ did not evaluate hepatic iron metabolism but instead examined the effects of TAA and $\mathrm{CCl}_{4}$ on hematologic parameters, providing important context to the changes in hepatic iron metabolism. They demonstrated that although long-term TAA treatment did not affect hemoglobin levels or red blood cell indexes, rats treated with $\mathrm{CCl}_{4}$ developed a microcytic anemic with significantly decreased serum iron and transferrin saturation. Serum ferritin increased in both models, although to a lesser degree in the $\mathrm{CCl}_{4}$-treated animals. In agreement with the study by Mueller et al, ${ }^{77}$ they found that TAA modestly depressed Hamp mRNA, but in contrast with the earlier work, they observed a twofold upregulation of Hamp mRNA by $\mathrm{CCl}_{4}$, consistent with the induction of IL6 in that model. These results suggest that the predominant effect of long-term $\mathrm{CCl}_{4}$ treatment on iron metabolism involves the development of anemia of inflammation or chronic disease. In this instance, the results of long-term treatment are similar to those of short-term $\mathrm{CCl}_{4}$ administration discussed above. The effects of longterm TAA treatment on iron homeostasis have not been examined in detail, but Mueller et $\mathrm{al}^{77}$ reported modest suppression of Hamp mRNA for $>6$ days after a single dose of TAA. Interestingly, this finding was associated with iron accumulation in macrophages but not hepatocytes. As discussed earlier, this pattern of iron accumulation presumably reflects the ingestion of necrotic cells and debris rather than lowered levels of hepcidin. Thus, the significance of the suppression of hepcidin in this context remains to be determined.

These studies demonstrate that although hepcidin expression is suppressed in several models of chronic liver injury, the effect of decreased levels of Hamp mRNA on iron status is inconsistent. Conversely, some of models of chronic liver injury are characterized by alterations in iron metabolism that are in keeping with anemia of chronic disease. Whether this variability is the consequence of differing mechanisms of injury or differing levels of opposing influences on hepcidin, such as inflammation and oxidative stress, is unclear. It is especially noteworthy that ostensibly similar models of toxic liver injury (TAA and $\mathrm{CCl}_{4}$ ) have contrasting effects on hepcidin and iron metabolism. Elevated levels of CHOP resulting from oxidative stress have been linked to suppression of hepcidin expression (Figure 1). The findings in mice receiving long-term TAA administration and in the hepatitis $\mathrm{C}$ virus transgenic mice discussed above are consistent with this mechanism. However, one might expect $\mathrm{CHOP}$ to increase in $\mathrm{CCl}_{4}$ administration as well, given that the toxicity of $\mathrm{CCl}_{4}$ is known to involve the generation of free radicals. The reason it does not and why different forms of liver injury have different impacts on hepcidin expression remain to be determined.

\section{Summary and Future Directions}

A few general observations emerge from this review. First, models of acute liver injury in rodents are often associated with elevated inflammatory mediators, upregulation of hepcidin gene expression, and hypoferremia (Figure 1). Although these events appear typical of an acute-phase response, the precise relationship between levels of hepcidin transcripts and changes in serum iron in these models deserves further 
attention. Reductions in serum iron that are not preceded by increases in Hamp mRNA have been termed hepcidinindependent hypoferremia. ${ }^{8,36,80,81}$ This phenomenon is not well understood, but its existence highlights the fact that little is known about the means by which the synthesis and secretion of hepcidin are regulated, whether there are factors that modulate the activity of hepcidin at the cellular level, and so on. A detailed understanding of these processes might shed light on the reasons that hepcidin transcript levels sometimes do not correspond with measurements of the peptide or propeptide in the blood and why serum iron levels sometimes decrease in the absence of changes in the latter. These are important questions for future study because of their implications for understanding not only the regulation of iron metabolism broadly but also specifically in the area of liver disease, where much of the existing data that implicate hepcidin in the dysregulation of iron metabolism is limited to measurements of hepcidin mRNA.

Second, this review shows that hepcidin expression is uniformly reduced in diverse models of chronic liver injury that span a wide spectrum of histologic severity. These studies support the concept that chronic liver injury is associated with suppression of hepcidin, but whether this is the primary or sole mechanism accounting for the dysregulation of iron metabolism in humans with chronic liver disease requires additional study. Caveats regarding the correlation or lack thereof between Hamp mRNA and its effects on iron metabolism apply equally to the chronic injury models reviewed here, which do not consistently demonstrate the alterations in iron metabolism that would be predicted to occur in response to reductions in hepcidin expression.

In a few instances, the apparent discrepancy between changes in hepcidin transcript levels and HICs was resolved when the effects of the chronic liver injury on iron metabolism at a systemic level were evaluated. Without data on serum iron parameters, red blood cell numbers and indexes, and/or rates of intestinal iron absorption, it is possible to misconstrue the significance of decreases in Hamp mRNA. The studies that found evidence of iron deficiency resulting from chronic liver injury cast reductions in Hamp mRNA in a far different light than might be assumed in the absence of this information. Furthermore, the fact that some models of liver injury are causes of iron deficiency is itself an intriguing finding that is deserving of investigation.

Future studies should examine how alterations in mechanisms that regulate iron metabolism evolve over time in response to liver injury. Any form of liver injury potentially involves the activation of multiple pathways, some of which have opposing effects on hepcidin expression. Information regarding the net effect of opposing inputs on hepcidin is limited, and even less is known about how the response to these inputs may change over time. ${ }^{66,82,83}$ For example, several of the models of acute liver injury (I-R, $\mathrm{CCl}_{4}$, and ionizing radiation) are classic examples of injuries caused by excessive free radical production. Why then do the effects of inflammation predominate over the hepcidin-suppressive effects of oxidative stress in the short-term setting, whereas in chronic liver injury downregulation of hepcidin expression is attributed to oxidative stress, notwithstanding the fact that inflammation and oxidative stress may also coexist in the latter? Whether this is explicable entirely because of the intensity of the signal remains to be determined, as does further information concerning the binary role of oxidative stress as both a positive regulator of hepcidin expression (via stimulation of BMP6 expression by SECs) and a negative regulator (based on its effects on CHOP, $\mathrm{C} / \mathrm{EBP} \alpha$, and so on). Additional information on these topics will help to clarify relationships among injury, hepcidin, and iron metabolism in chronic liver disease.

\section{References}

1. Ganne-Carrié N, Christidis C, Chastang C, Ziol M, Chapel F, Imbert-Bismut F, Trinchet J, Guettier C, Beaugrand M: Liver iron is predictive of death in alcoholic cirrhosis: a multivariate study of 229 consecutive patients with alcoholic and/or hepatitis C virus cirrhosis: a prospective follow up study. Gut 2000, 46: $277-282$

2. George DK, Goldwurm S, MacDonald GA, Cowley LL, Walker NI, Ward PJ, Jazwinska EC, Powell LW: Increased hepatic iron concentration in nonalcoholic steatohepatitis is associated with increased fibrosis. Gastroenterology 1998, 114:311-318

3. Hezode C, Cazeneuve C, Coue O, Roudot-Thoraval F, Lonjon I, Bastie A, Duvoux C, Pawlotsky JM, Zafrani ES, Amselem S, Dhumeaux D: Liver iron accumulation in patients with chronic active hepatitis C: prevalance and role of hemochromatosis gene mutations and relationship with hepatic histological lesions. J Hepatol 1999, 31: 979-984

4. Pietrangelo A: Iron in NASH, chronic liver diseases and HCC: how much iron is too much? J Hepatol 2009, 50:249-251

5. Pigeon C, Ilyin G, Courselaud B, Leroyer P, Turlin B, Brissot P, Loréal P: A new mouse liver-specific gene, encoding a protein homologous to human antimicrobial peptide hepcidin, is overexpressed during iron overload. J Biol Chem 2001, 276: $7811-7819$

6. Park CH, Valore EV, Waring AJ, Ganz T: Hepcidin, a urinary antimicrobial peptide synthesized in the liver. J Biol Chem 2001, 276: $7806-7810$

7. Nemeth E, Tuttle MS, Powelson J, Vaughn MB, Donovan A, Ward DM, Ganz T, Kaplan J: Hepcidin regulates cellular iron efflux by binding to ferroportin and inducing its internalization. Science 2004, 306:2090-2093

8. Constante M, Jiang W, Wang D, Raymond VA, Bilodeau M Santos MM: Distinct requirements for Hfe in basal and induced hepcidin levels in iron overload and inflammation. Am J Physiol 2006, 291:G229-G237

9. Brown KE, Broadhurst KA, Mathahs MM, Weydert J: Differential expression of stress-inducible proteins in chronic hepatic iron overload. Toxicol Appl Pharmacol 2007, 223:180-186

10. Babitt JL, Huang FW, Wrighting DM, Xia Y, Sidis Y, Samad TA, Campagna JA, Chung RT, Schneyer AL, Woolf CJ, Andrews NC, Lin HY: Bone morphogenetic protein signaling by hemojuvelin regulates hepcidin expression. Nat Genet 2006, 38: $531-539$

11. Wang CY, Xu Y, Traeger L, Dogan DY, Xiao X, Steinbicker AU, Babitt JL: Erythroferrone lowers hepcidin by sequestering BMP2/6 
heterodimer from binding to the BMP type I receptor ALK3. Blood 2020, 135:453-456

12. Gao J, Chen J, De Domenico I, Koeller DM, Harding CO, Fleming RE, Koeberl DD, Enns CA: Hepatocyte-targeted HFE and TFR2 control hepcidin expression in mice. Blood 2010, 115:3374-3381

13. Latour C, Besson-Fournier C, Meynard D, Silvestri L, Gourbeyre O, Aguilar-Martinez P, Schmidt PJ, Fleming MD, Roth MP, Coppin H: Differing impact of the deletion of hemochromatosis-associated molecules HFE and transferrin receptor-2 on the iron phenotype of mice lacking bone morphogenetic protein 6 or hemojuvelin. Hepatology 2016, 63:126-137

14. Knittel T, Fellmer P, Mueller L, Ramadori G: Bone morphogenetic protein-6 is expressed in nonparenchymal liver cells and upregulated by transforming growth factor-b1. Exp Cell Res 1997, 232:262-269

15. Zhang A-S, Anderson SA, Wang J, Yang F, DeMaster K, Ahmed R, Nizzi CP, Eisenstein RS, Tsukamoto H, Enns CA: Suppression of hepatic hepcidin expression in response to acute iron deprivation is associated with an increase in matriptase-2 protein. Blood 2011, 117: 1687-1699

16. Enns CA, Ahmed R, Wang J, Ueno A, Worther C, Tsukamoto H, Zhang A-S: Increased iron loading induces Bmp6 expression in the non-parenchymal cells of the liver independent of the BMP-signaling pathway. PLoS One 2013, 8:e60534

17. Canali S, Zumbrennen-Bullough KB, Core AB, Wang C-Y, Nairz M, Bouley R, Swirski FK, Babitt JL: Endothelial cells produce bone morphogenetic protein 6 required for iron homeostasis in mice. Blood 2017, 129:405-414

18. Lim PJ, Duarte TL, Arezes J, Garcia-Santos D, Hamdi A, Pasricha SR, Armitage AE, Mehta H, Wideman S, Santos AG, Santos-Gonçalves A, Morovat A, Hughes JR, Soilleux E, Wang CY, Bayer AL, Klenerman P, Willberg CB, Hartley RC, Murphy MP, Babitt JL, Ponka P, Porto G, Drakesmith H: Nrf2 controls iron homoeostasis in haemochromatosis and thalassaemia via Bmp6 and hepcidin. Nat Metab 2019, 1:519-531

19. Wang CY, Babitt JL: Liver iron sensing and body iron homeostasis. Blood 2019, 133:18-2916

20. Zhou XY, Tomatsu S, Fleming RE, Parkkila S, Waheed A, Jiang J, Fei Y, Brunt EM, Ruddy DA, Prass CE, Schatzman RC, O'Neill R, Britton RS, Bacon BR, Sly WS: HFE gene knockout produces mouse model of hereditary hemochromatosis. Proc Natl Acad Sci 1998, 95: 2492-2497

21. Delima RD, Chua ACG, Tirnitz-Parker JEE, Gan EK, Croft KD, Graham RM, Olynyk JK, Trinder D: Disruption of hemochromatosis protein and transferrin receptor 2 causes iron-induced liver injury in mice. Hepatology 2012, 56:585-593

22. Ahmad KA, Ahmann JR, Migas MC, Waheed A, Britton RS, Bacon BR, Sly WS, Fleming RE: Decreased liver hepcidin expression in the Hfe knockout mouse. Blood Cells Mol Dis 2002, 29:361-366

23. Nicolas G, Viatte L, Lou DQ, Bennoun M, Beaumont C, Kahn A, Andrews NC, Vaulont S: Constitutive hepcidin expression prevents iron overload in a mouse model of hemochromatosis. Nat Genet 2003, 34:97-101

24. Kawabata H, Fleming RE, Gui D, Moon SY, Saitoh T, O'Kelly J, Umehara Y, Wano Y, Said JW, Koeffler HP: Expression of hepcidin is down-regulated in TfR2 mutant mice manifesting a phenotype of hereditary hemochromatosis. Blood 2005, 105:376-381

25. Wallace DF, Summerville L, Subramaniam VN: Targeted disruption of the hepatic transferrin receptor 2 gene in mice leads to iron overload. Gastroenterology 2007, 132:301-310

26. Niederkofler V, Salie R, Arber S: Hemojuvelin is essential for dietary iron sensing, and its mutation leads to severe iron overload. J Clin Invest 2005, 115:2180-2186

27. Meynard D, Kautz L, Darnaud V, Canonne-Hergaux F, Coppin H, Roth MP: Lack of the bone morphogenetic protein BMP6 induces massive iron overload. Nat Genet 2009, 41:478-481
28. Camaschella C, Roetto A, Calì A, De Gobbi M, Garozzo G, Carella M, Majorano N, Totaro A, Gasparini P: The gene TFR2 is mutated in a new type of haemochromatosis mapping to $7 \mathrm{q} 22$. Nat Genet 2000, 25:14-15

29. Papanikolaou G, Samuels ME, Ludwig EH, MacDonald MLE, Franchini PL, Dubé MP, Andres L, MacFarlane J, Sakellaropoulos N, Politou M, Nemeth E, Thompson J, Risler JK, Zaborowska C, Babakaiff R, Radomski CC, Pape TD, Davidas O, Christakis J, Brissot P, Lockitch G, Ganz T, Hayden MR, Goldberg YP: Mutations in HFE2 cause iron overload in chromosome 1q-linked juvenile hemochromatosis. Nat Genet 2004, 36:77-82

30. Daher R, Kannengiesser C, Houamel D, Lefebvre T, BardouJacquet E, Ducrot N, de Kerguenec C, Jouanolle AM, Robreau AM, Oudin C, Le Gac G, Moulouel B, Loustaud-Ratti V, Bedossa P, Valla D, Gouyal L, Beaumont C, Brissot P, Puy H, Karim Z, Tchernitchko D: Heterozygous mutations in BMP6 pro-peptide lead to inappropriate hepcidin synthesis and moderate iron overload in humans. Gastroenterology 2016, 150:672-683

31. Kampschmidt RF, Schultz GA: Hypoferremia in rats following injection of bacterial endotoxin. Proc Soc Exp Biol Med 1961, 106: $870-871$

32. Wrighting DM, Andrews NC: Interleukin-6 induces hepcidin expression through STAT3. Blood 2006, 108:3204-3209

33. Pietrangelo A, Dierssen U, Valli L, Garuti C, Rump A, Corradini E, Ernst M, Klein C, Trautwein C: STAT3 Is required for IL-6gp130-dependent activation of hepcidin in vivo. Gastroenterology 2007, 132:294-300

34. Inamura J, Ikuta $\mathrm{K}$, Jimbo J, Shindo M, Sato K, Torimoto $\mathrm{Y}$, Kohgo Y: Upregulation of hepcidin by interleukin-1beta in human hepatoma cell lines. Hepatol Res 2005, 33:198-205

35. Ramadori P, Ahmad G, Ramadori G: Cellular and molecular mechanisms regulating the hepatic erythropoietin expression during acutephase response: a role for IL-6. Lab Invest 2010, 90:1306-1324

36. Laftah AB, Sharma N, Brookes MJ, McKie AT, Simpson RJ, Iqbal TH, Tselepsis C: Tumour necrosis factor alpha causes hypoferraemia and reduced intestinal iron absorption in mice. Biochem $\mathrm{J}$ 2006, 397:61-67

37. Sheikh N, Dudas J, Ramadori G: Changes in gene expression of iron regulatory proteins during turpentine oil-induced acute-phase response in the rat. Lab Invest 2007, 87:713-725

38. Vecchi C, Montosi G, Zhang K, Lamberti I, Duncan SA, Kaufman RJ, Pietrangelo A: ER stress controls iron metabolism through induction of hepcidin. Science 2009, 325:877-880

39. Nemeth E, Rivera S, Gabayan V, Keller C, Taudorf S, Pedersen BK, Ganz T: IL-6 mediates hypoferremia of inflammation by inducing the synthesis of the iron regulatory hormone hepcidin. J Clin Invest 2004, 113:1271-1276

40. Rivera S, Nemeth E, Gabayan V, Lopez MA, Farshidi D, Ganz T: Synthetic hepcidin causes rapid dose-dependent hypoferremia and is concentrated in ferroportin-containing organs. Blood 2005, 106: 2196-2199

41. Viatte L, Nicolas G, Lou DQ, Bennoun M, Lesbordes-Brion JC, Canonne-Hergaux F, Schönig K, Bujard H, Kahn A, Andrews NC, Vaulont S: Chronic hepcidin induction causes hyposideremia and alters the pattern of cellular iron accumulation in hemochromatotic mice. Blood 2006, 107:2952-2958

42. Burgess-Beusse BL, Darlington GJ: C/EBP $\alpha$ is critical for the neonatal acute-phase response to inflammation. Mol Cell Biol 1998, 18:7269-7277

43. Courselaud B, Pigeon C, Inoue Y, Inoue J, Gonzalez FJ, Leroyer P, Gilot D, Boudjema K, Guguen-Guillouzo C, Brissot P, Loréal O, Ilyin $\mathrm{G}$ : $\mathrm{C} / \mathrm{EBP} \alpha$ regulates hepatic transcription of hepcidin, an antimicrobial peptide and regulator of iron metabolism. J Biol Chem 2002, 277:41163-41170

44. Mackey SL, Darlington GJ: CCAAT enhancer-binding protein $\alpha$ is required for interleukin-6 receptor $\alpha$ signaling in newborn hepatocytes. J Biol Chem 2004, 279:16206-16213 
45. Bloomer SA, Brown KE: Tumour promotion versus tumour suppression in chronic hepatic iron overload. Cell Biochem Funct 2015, $33: 241-248$

46. Kautz L, Jung G, Valore EV, Rivella S, Nemeth E, Ganz T: Identification of erythroferrone as an erythroid regulator of iron metabolism. Nat Genet 2014, 46:678-684

47. Ramadori P, Sheikh N, Ahmad G, Dudas J, Ramadori G: Hepatic changes of erythropoietin gene expression in a rat model of acutephase response. Liver Int 2010, 30:55-64

48. Goss JA, Seu P, Gao FQ, Wyllie S: Ischemia-reperfusion of rat liver modulates hepcidin in vivo expression. Liver Transpl 2005, 11: 800-806

49. Sheikh N, Batusic DS, Dudas J, Tron K, Neubauer K, Saile B, Ramadori G: Hepcidin and hemojuvelin gene expression in rat liver damage: in vivo and in vitro studies. Am J Physiol 2006, 291: G482-G490

50. Mollbrink A, Holmstrom P, Sjostrom M, Hultcrantz R, Eriksson LC, Stal P: Iron-regulatory gene expression during liver regeneration. Scand J Gastroenterol 2012, 47:591-600

51. Wang L, Gao F, Yang F, Wei Z, Zou C: Hepcidin plays a negative role in liver regeneration. Acta Biochim Biophys Sin 2013, 45: 1049-1054

52. Christiansen H, Sheikh N, Saile B, Reuter F, Rave-Fraenk M, Hermann RM, Dudas J, Hille A, Hess CF, Ramadori G: X-irradiation in rat liver: consequent upregulation of hepcidin and downregulation of hemojuvelin and ferroportin-1 gene expression. Radiology 2007, 242:189-197

53. Spivak I, Arora J, Meinzer C, Durkalski-Mauldin V, Lee WM, Trautwein C, Fontana RJ, Strnad P; Acute Liver Failure Study Group (ALFSG): Low serum hepcidin is associated with reduced short-term survival in adults with acute liver failure. Hepatology 2019, 69: 2136-2149

54. Bridle K, Cheung TK, Murphy T, Walters M, Andersen G, Crawford DG, Fletcher LM: Hepcidin is down-regulated in alcoholic liver injury: implications for the pathogenesis of alcoholic liver disease. Alcohol Clin Exp Res 2006, 30:106-112

55. Harrison-Findik DD, Schafer D, Klein E, Timchenko NA, Kulaksiz H, Clemens D, Fein E, Andriopoulos B, Pantopoulos K, Gollan J: Alcohol-metabolism-mediated oxidative stress down-regulates hepcidin transcription and leads to increased duodenal iron transporter expression. J Biol Chem 2006, 281:22974-22982

56. Ohtake T, Saito H, Hosoki Y, Inoue M, Miyoshi S, Suzuki Y, Fujimoto Y, Kohgo Y: Hepcidin is down-regulated in alcohol loading. Alcohol Clin Exp Res 2007, 31:S2-S8

57. Tang Y, Li Y, Yu H, Gao C, Liu L, Chen S, Xing M, Liu L, Yao P: Quercetin prevents ethanol-induced iron overload by regulating hepcidin through the BMP6/SMAD4 signaling pathway. J Nutr Biochem 2014, 25:675-682

58. Heritage ML, Murphy TL, Bridle KR, Anderson GJ, Crawford DHG, Fletcher LM: Hepcidin regulation in wild-type and Hfe knockout mice in response to alcohol consumption: evidence for an alcoholinduced hypoxic response. Alcohol Clin Exp Res 2009, 33: $1391-1400$

59. Flanagan JM, Peng HF, Butler E: Effects of alcohol consumption on iron metabolism in mice with hemochromatosis mutations. Alcohol Clin Exp Res 2007, 31:138-143

60. Varghese J, Varghese James J, Sagi S, Chakraborty S, Sukumaran A, Ramakrishnan B, Jacob M: Decreased hepatic iron in response to alcohol may contribute to alcohol-induced suppression of hepcidin. Br J Nutr 2016, 115:1978-1986

61. Bloomer SA, Broadhurst KA, Mathahs MM, Brown KE: Effects of long-term ethanol ingestion on hepatic iron metabolism in 2 mouse strains. Clin Exp Pharmacol Physiol 2021, 48:534-542

62. Le Guenno G, Chanseaume E, Ruivard M, Morio B, Mazur A: Study of iron metabolism disturbances in an animal model of insulin resistance. Diabetes Res Clin Pract 2007, 77:363-370
63. Chung J, Kim MS, Han SN: Diet-induced obesity leads to decreased hepatic iron storage in mice. Nutr Res 2011, 31:915-921

64. Sonnweber T, Ress C, Nairz M, Theurl I, Schroll A, Murphy AT, Wroblewski V, Witcher DR, Moser P, Ebenbichler CF, Kaser S, Weiss G: High-fat diet causes iron deficiency via hepcidinindependent reduction of duodenal iron absorption. J Nutr Biochem 2012, 23:1600-1608

65. Padda RS, Gkouvatsos K, Guido M, Mui J, Vali H, Pantopoulos K: A high-fat diet modulates iron metabolism but does not promote liver fibrosis in hemochromatotic $\mathrm{Hjv}^{-/-}$mice. Am J Physiol 2015, 308: G251-G261

66. Bloomer SA, Olivier AK, Bergmann OM, Mathahs MM, Broadhurst KA, Hicsasmaz MH, Brown KE: Strain-and timedependent alterations in hepatic iron metabolism in a murine model of non-alcoholic steatohepatitis. Cell Biochem Funct 2016, 34: 628-639

67. Varghese J, James JV, Anand R, Narayanasamy M, Rebekah G, Ramakrishna B, Nellickal AJ, Jacob M: Development of insulin resistance preceded major changes in iron homeostasis in mice fed a high-fat diet. J Nutr Biochem 2020, 84:108441

68. Tsuchiya H, Ebata Y, Sakabe T, Hama S, Kogure K, Shiota G: Highfat, high-fructose diet indices hepatic iron overload via a hepcidinindependent mechanism prior to the onset of liver steatosis and insulin resistance in mice. Metabolism 2013, 62:62-69

69. Batey RG, Johnston R: Effects of alcohol, carbon tetrachloride, and choline deficiency on iron metabolism in the rat. Alcohol Clin Exp Res 1993, 17:931-934

70. Olynyk J, Hall P, Reed W, Williams P, Kerr R, Mackinnon M: A long-term study of the interaction between iron and alcohol in an animal model of iron overload. J Hepatol 1995, 22:671-676

71. Gentry-Nielsen MJ, Preheim LC, Lyman KN, McDonough KH, Potter BJ: Use of rat models to mimic alterations in iron homeostasis during human alcohol abuse and cirrhosis. Alcohol 2001, 23:71-81

72. Bekri S, Gual P, Anty R, Luciani N, Dahman M, Ramesh B, Iannelli A, Staccini-Myx A, Casanova D, Ben Amor I, SaintPaul MC, Huet PM, Sadoul JL, Gugenheim J, Srai SKS, Tran A, Le Marchand-Brustel Y: Increased adipose tissue expression of hepcidin in severe obesity is independent from diabetes and NASH. Gastroenterology 2006, 131:788-796

73. Nishina S, Hino K, Korenaga M, Vecchi C, Pietrangelo A, Nizukami Y, Furutani T, Sakai A, Okuda M, Hidaka I, Okita K, Sakaida I: Hepatitis C virus-induced reactive oxygen species raise hepatic iron level by reducing hepcidin transcription. Gastroenterology 2008, 134:226-238

74. Huang Y-H, Chuang J-H, Yang Y-L, Huang C-C, Wu C-L, Chen C$\mathrm{L}$ : Cholestasis downregulate hepcidin expression through inhibiting IL-6-induced phosphorylation of signal transducer and activator of transcription 3 signaling. Lab Invest 2009, 89:1128-1139

75. Suzuki T, Hanawa H, Jiao S, Ohno Y, Hayashi Y, Yoshida K, Kashimura T, Obata H, Minamino T: Inappropriate expression of hepcidin by liver congestion contributes to anemia and relative iron deficiency. J Card Fail 2014, 20:268-277

76. Bao WD, Fan Y, Deng YZ, Long LY, Wang JJ, Guan DX, Qian ZY, An P, Feng YY, He ZY, Wang XF, Koeffler HP, Hu R, Wang J, Want X, Wang F, Li FF, Xie D: Iron overload in hereditary tyrosinemia type 1 induces liver injury through the Sp1/Tfr2/hepcidin axis. J Hepatol 2016, 65:137-145

77. Mueller K, Sunami Y, Stuetzle M, Guldiken N, Kucukglu O, Mueller S, Kulaksiz H, Schwarz P, Strnad P: CHOP-mediated hepcidin suppression modulates hepatic iron load. J Pathol 2013, 231: $532-542$

78. Gheith I, El-Mahmoudy A: Hepcidin-orchestrated hemogram and iron homeostatic patterns in two models of subchronic hepatic injury. Biomed Environ Sci 2019, 32:153-161

79. Ludwig J, Hashimoto E, Porayko MK, Moyer TP, Baldus WP: Hemosiderosis in cirrhosis: a study of 447 native livers. Gastroenterology 1997, 112:882-888 
80. Layoun A, Huang H, Calve A, Santos MM: Toll-like receptor signal adaptor protein MyD88 is required for sustained endotoxin-induced acute hypoferremic response in mice. Am J Pathol 2012, 180: $2340-2350$

81. Bloomer SA, Kregel KC, Brown KE: Heat stress stimulates hepcidin mRNA expression and $\mathrm{C} / \mathrm{EBP} \alpha$ protein expression in aged rodent liver. Arch Gerontol Geriatr 2014, 58:145-152
82. Darshan D, Frazer DM, Wilkins SJ, Anderson GJ: Severe iron deficiency blunts the response of the iron regulatory gene Hamp and proinflammatory cytokines to lipopolysaccharide. Haematologica 2010, 95:1660-1667

83. Huang H, Constante M, Layoun A, Santos MM: Contribution of STAT3 and SMAD4 pathways to the regulation of hepcidin by opposing stimuli. Blood 2009, 113:3593-3599 